Szendy Viktória Anna ${ }^{1}$

\title{
A védelmi igazgatás és a katasztrófavédelem nemzeti rendszere - a kormányzati szint
}

\section{The National System of Defence Management and Disaster Management - The Level of Government}

\begin{abstract}
Absztrakt
A két részből álló tanulmány a védelmi igazgatás és a katasztrófavédelem kapcsolatát elemzi. A tanulmány első része bemutatja a közigazgatás és a védelmi igazgatás kapcsolatát, különös tekintettel a veszélyhelyzetre és katasztrófaveszélyre, továbbá Magyarország katasztrófavédelmi rendszerének felépitését, müködési sajátosságait, különös tekintettel a katasztrófavédelem központi - kormányzati -szintjére.
\end{abstract}

Kulcsszavak: biztonság, veszélyhelyzet, Kormány, belügyminiszter, Katasztrófavédelmi Koordinációs Tárcaközi Bizottság

\section{Abstract}

The two-part study analyses the relationship between defence management and disaster management. The first part of the study presents the relationship between public administration and defence administration, with particular regard to the emergency and disaster risks.

In addition, the structure and operational features of Hungary's disaster management system will be described, with particular reference to the central level of government of disaster management.

Keywords: security, emergency, Government

Pest Megyei Katasztrófavédelmi Igazgatóság, előadó, Disaster Management of Pest County, lecturer, e-mail: ria.szendy@ gmail.com, ORCID: https://orcid.org/0000-0001-6140-3469 


\section{Bevezetés}

A 21. századra megváltoztak a világban - így Magyarországon is - a biztonságot fenyegető kihívások és kockázatok. Ezek a korábbi időszakokban - egészen a 20. század utolsó évtizedéig - elsősorban katonai kihívások voltak, emiatt az országok inkább a katonai (hon)védelmet ellátni képes fegyveres erőket fejlesztették, ez a terület kapott kiemelt figyelmet.

A 20. század végétől - bár a katonai jellegü kihívások továbbra is jelentősek maradtak - előtérbe kerültek a biztonságot fenyegető más jellegü kockázatok és kihívások is. Ezek jellegét sok tényező befolyásolja: a globalizáció, a nemzetközi szintủ biztonság, a nemzetközi szintű kihívások kezelése, a transzatlanti kapcsolatok, egyéb szövetségek és ezek hatásai. Ezekre a kihívásokra kell megoldást találnia Magyarországnak, amelyet az ország közigazgatási rendszerének keretein belül tud megtenni.

A két egymáshoz kapcsolódó tanulmányban bemutatom a biztonságot fenyegető egyik veszélyforrás kezelésére - a természeti, az ipari és egyéb típusú katasztrófák megelőzésére, az ellenük való védekezésre és a következmények felszámolására - létrehozott szervezetrendszert és annak elemeit.

Az első tanulmányban ismertetem ennek kormányzati szintjét, míg a másodikban a hivatásos katasztrófavédelmi szervezetrendszert mutatom be.

\section{A közigazgatás és a védelmi igazgatás kapcsolata}

A közigazgatás a végrehajtó-hatalom elkülönült szervezetrendszerének és személyi állományának a jog által meghatározott tevékenysége, amellyel a társadalom tagjait és szervezeti magatartását a közhatalom birtokában befolyásolja. A közigazgatásnak két alapfunkciója van: társadalomirányítási (közhatalmi) és a társadalomszervezési (igazgatási), ezeken belül pedig több funkció is megjelenik, például a gazdasági és védelmi funkció. A védelmi funkció magába foglalja a külső- (szuverenitás, függetlenség), belső- (rendvédelem, közbiztonság) és a katasztrófavédelmi (környezeti biztonság) területeket is.

A védelmi igazgatás a közigazgatás részét képező feladat- és eszközrendszer, amelyet az állam a védelmi feladatainak megvalósítására hozott létre, valamint jelenti aze feladatokra kijelölt szervek által végzett tervező, szervező, rendelkező tevékenységet, magában foglalja ezen kívül a különleges jogrendre történő felkészülést, továbbá az említett időszakok és helyzetek honvédelmi, katasztrófavédelmi feladatainak tervezésére, szervezésére, a feladatok végrehajtására irányuló tevékenységek összességét. ${ }^{2}$ Gyakorlatilag tehát megállapítható, hogy a közigazgatás védelmi funkciói ellátásának megszervezéséért a védelmi igazgatás felel.

A védelmi igazgatás funkciói: az állami (központi, területi, helyi) irányítás és vezetés folyamatosságának, fenntartásának biztosítása, a védekezés irányítása, koordinálása, az adott védelmi feladatra rendelt szervezet müködési feltételeinek biztosítása, támogatása, a lakosság és az anyagi javak védelme, a nemzetgazdaság erőforrásainak 
mobilizálása, a gazdaság védelme, valamint a vállalt nemzetközi kötelezettségek teljesítése.

A védelmi igazgatás több alrendszerrel rendelkezik, ezen belül két alapvető területe a honvédelmi és a katasztrófavédelmi igazgatás.

„Az állam feladata többek közt a lakosság életének, vagyonának védelme. E feladatának teljesítésére a védekezést irányító, koordináló, szabályzó tevékenységet lát el. A védekezés megköveteli a szervezett együttmüködést, melyben a lakosság és a védekezésre létrehozott szervek együttműködése valósul meg. A védekezési feladatokban továbbra is megmaradt a települések kiemelt szerepe. Az államnak, az önkormányzatoknak, a közigazgatásnak tehát kiemelt szerepe van a katasztrófák elleni védekezés megelőzési, védekezési és az azt követő helyreállítási tevékenységekben." ${ }^{3}$

\section{Katasztrófavédelmi igazgatás}

A katasztrófavédelmi igazgatás a védelmi igazgatás részét képező feladat- és szervezetrendszer, amelynek keretében a katasztrófák ellen létrehozott, valamint e feladatra kijelölt rendvédelmi és közigazgatási szervek, továbbá a katasztrófavédelemben közreműködő más szervek ellátják a katasztrófavédelemről és a hozzá kapcsolódó egyes törvények módosításáról szóló 2011. évi CXXVIII. törvényben meghatározottak teljesítésével kapcsolatos feladatokat.

A katasztrófavédelmi igazgatás funkciói a következők:

- a katasztrófák elleni védekezés megszervezése, a védekezésben részt vevő szervek és szervezetek tevékenységének irányítása, koordinálása,

- a katasztrófák elleni védekezés érdekében létrehozott, illetve a védekezésben részt vevő szervezetek müködési feltételeinek biztosítása,

- a különböző katasztrófavédelmi ágazatok, területek feladatainak elvégzése,

- a lakosság életének és az anyagi javainak megóvása, polgári védelmi feladatainak megtervezése és biztosítása,

- a katasztrófavédelmi szempontból vállalt nemzetközi kötelezettségek teljesítése.

A katasztrófavédelmi igazgatás funkcióit három területre lehet osztani: tűzvédelem, iparbiztonság és polgári védelem, amelyek azonban teljes mértékben egymástól nem különíthetők el.

Két olyan - a normál időszaki jogrendtől részben, vagy egészében elkülönülő - jogrendi állapot van, amelyek kezelése elsősorban a hivatásos katasztrófavédelmi szerv feladata: a veszélyhelyzet és a katasztrófaveszély. ${ }^{4}$

A katasztrófaveszély „olyan folyamat vagy állapot, amelynek következményeként okszerüen lehet számolni a katasztrófa bekövetkezésének valószínüségével, és amely ezáltal veszélyezteti az emberi egészséget, környezetet, az élet- és vagyonbiztonságot."

Schweickhardt Gotthilf: A katasztrófavédelem rendszere, Nemzeti Közszolgálati Egyetem, Dialóg Campus Kiadó, Budapest, 2018, 10.

4 Ezen események kezelésébe jogszabályi keretek között bármely társszerv bevonható, de a feladatok végrehajtását a hivatásos katasztrófavédelmi szerv irányítja.

2011. évi CXXVIII. törvény a katasztrófavédelemröl és a hozzá kapcsolódó egyes törvények módosításáról 3. § 9. pont. 
A katasztrófaveszély jellege tehát nem éri el a különleges jogrendi állapotot, ezért nem az Alaptörvény, hanem a katasztrófavédelemröl és a hozzá kapcsolódó egyes törvények módosításáról szóló 2011. évi CXXVIII. törvény határozza meg fogalmát, illetve rendelkezik róla.

Katasztrófaveszély fennállásának esetén a hivatásos katasztrófavédelmi szerv teljes, vagy részleges állományának elrendelhető a feladat-végrehajtásra való készenlét, valamint a katasztrófák elleni védekezésért felelős miniszter (belügyminiszter) által jóváhagyott központi veszélyelhárítási tervben meghatározott egyéb intézkedéseket is elrendelheti a hivatásos katasztrófavédelmi szerv központi szervének vezetője (BM Országos Katasztrófavédelmi Főigazgatóság főigazgató). ${ }^{6}$

Fontos kiemelni, hogy a lakosságot ezek az intézkedések semmilyen formában nem érintik, amennyiben azonban más állami szerv segítségére szükség van, azokat az irányításukra kijelölt ágazati miniszter vagy a Kormány döntése alapján vonják be a katasztrófavédelmi feladatokba.

Ezzel ellentétben a veszélyhelyzet ${ }^{7}$ az Alaptörvényben szabályozott különleges jogrendi állapot, amely során a Kormány az élet- és vagyonbiztonságot veszélyeztető elemi csapás vagy ipari szerencsétlenség esetén, valamint ezek következményeinek az elhárítása érdekében kihirdeti e különleges jogrendi időszak életbelépését, és a katasztrófavédelmi törvényben meghatározott rendkívüli intézkedéseket vezethet be. A különleges kormányrendeleti formában meghozott rendkívüli intézkedések egyes törvények alkalmazását felfüggeszthetik, a hatályos törvényektől eltérő szabályozást vezethetnek be, de azok csak 15 napig hatályosak, hacsak az Országgyülés felhatalmazására a Kormány meg nem hosszabbítja azok időbeli hatályát. A rendkívüli intézkedések - amint a veszélyhelyzet különleges jogrend megszűnik - hatályukat vesztik.

\section{Kormányzati szint}

Tekintettel arra, hogy a katasztrófák megelőzése és az ellenük való védekezés több ágazatot érintő feladat, annak megszervezése a Kormány feladatkörébe tartozik.

„A katasztrófavédelmi törvény meghatározza, hogy a katasztrófavédelem irányítása a szakirányítást végző kormányzati szerveken keresztül valósul meg. Ezzel egyértelművé válik, hogy a kormány nem közvetlenül, hanem közvetve végzi az irányítási feladatait."

Ezek a feladatok elsősorban szervezési, koordinálási és irányítási tevékenységek, amelynek keretében a Kormány: ${ }^{9}$

- meghatározza az érintett állami szerveknek a katasztrófavédelemmel kapcsolatos feladatait,

2011. évi CXXVIII. törvény a katasztrófavédelemről és a hozzá kapcsolódó egyes törvények módosításáról 43. §. Magyarország Alaptörvénye 53. cikk.

Endrődi István: A katasztrófavédelem tevékenysége veszélyhelyzeti feladatok végrehajtása során, in: Kovács Gábor (szerk.), A rendészeti, honvédségi, közigazgatási és nemzetközi szervezetek tevékenysége veszélyhelyzet-ben, A „Vihar-2016" Egyetemi Közös Közszolgálati Gyakorlat tapasztalatai, Nemzeti Közszolgálati Egyetem, Budapest, 2016, 287.

9 2011. évi CXXVIII. törvény a katasztrófavédelemröl és a hozzá kapcsolódó egyes törvények módosításáról 5. §. 
- megköti a katasztrófavédelemmel kapcsolatos együttmüködésre irányuló nemzetközi egyezményeket,

- összehangolja a katasztrófavédelemmel összefüggő oktatási, képzési, tudományos kutatási és múszaki fejlesztési tevékenységet,

- létrehozza az országos katasztrófavédelmi információs rendszert,

- kihirdetésre előkészíti a veszélyhelyzet idején bevezetendő rendeletek tervezeteit, és megküldi azokat a végrehajtásért felelős személyeknek és szervezeteknek,

- gondoskodik a központi költségvetési tervezés keretében a katasztrófavédelem müködésének és fejlesztésének pénzügyi feltételeiről,

- meghatározza a nemzeti kockázatelemzési, -értékelési és feltérképezési követelményeket,

- a belügyminiszter és a honvédelmi miniszter véleményének kikérését követően meghatározza a polgári védelmi szervezetek összlétszámát,

- a belügyminiszter útján irányítja a megyei védelmi bizottságok katasztrófavédelmi feladatainak végrehajtását.

\section{Belügyminiszter}

Belügyminiszteri szinten jelennek meg azok a tevékenységi körök, amelyek például a katasztrófavédelem megszervezésének kormányzati feladataival, a nemzetközi szakmai együttmüködéssel, a kritikus infrastruktúrák védelmének megszervezésével, az ezekkel összefüggő ágazati feladatokkal kapcsolatosak.

A belügyminiszter feladatai a katasztrófavédelem rendszerében: ${ }^{10}$

- felelös az irányítása alá tartozó hivatásos katasztrófavédelmi szerv múködtetéséért,

- kinevezi, illetve felmenti a közvetlen irányítása alá tartozó hivatásos katasztrófavédelmi szerv (BM OKF) vezetőjét, felmenti annak helyettesét vagy helyetteseit,

- elrendeli a Kormány egyidejű tájékoztatása mellett a polgári védelmi szervezetek részleges alkalmazását,

- háromévente jelentést készít az Országgyülésnek és a Kormánynak a föbb természeti csapásokra és az ember okozta katasztrófákra kiterjedő kockázatelemzésekről, a katasztrófák elleni védekezésre történő felkészülés helyzetéről, illetve a védekezésről,

- gondoskodik a polgári veszélyhelyzeti tervezés (NATO CEP) katasztrófavédelmi feladatainak hazai koordinálásáról és végrehajtásáról, amelynek érdekében biztosítja a képviseletet a NATO Polgári Veszélyhelyzeti Tervezési Bizottságban (NATO CEPC), ellátja a NATO CEPC katasztrófavédelmi szerveivel való kapcsolattartást,

10 2011. évi CXXVIII. törvény a katasztrófavédelemröl és a hozzá kapcsolódó egyes törvények módosításáról 8. §, illetve 234/2011. (XI. 10.) Korm. rendelet a katasztrófavédelemről és a hozzá kapcsolódó egyes törvények módosításáról szóló 2011. évi CXXVIII. törvény végrehajtásáról 5. §. 
- gondoskodik az EU polgári védelmi tevékenységének hazai koordinálásáról és végrehajtásáról, ennek keretében biztosítja a kapcsolattartást és a képviseletet az EU intézményeiben,

- részt vesz a nemzetközi segítségnyújtásban,

- felelős a kritikus infrastruktúrák védelméért a katasztrófák elleni védekezés területén,

- jóváhagyja a központi veszélyelhárítási tervet,

- figyelemmel kíséri a szakterületén jelentkező, katasztrófaveszélyt jelentő jelenségeket, folyamatokat, intézkedik a veszély elhárítására, illetve megteszi a szükséges intézkedéseket a megelőzéshez szükséges pénzügyi források biztosítására, a feladatok végrehajtására, gondoskodik a veszélyhelyzetet okozó emberi tevékenységek és a környezeti elemek körében a kockázat csökkentéséhez, a károk bekövetkezésének megelőzéséhez szükséges katasztrófavédelmi tervezési, kivitelezési, működtetési, ellenőrzési és biztonsági szabályok megállapításáról,

- gondoskodik az ágazat figyelö- és ellenőrzőrendszerének az egységes irányítási rendszerbe illeszkedő kiépítéséről és működtetéséről, valamint az ágazati adatszolgáltatási kapcsolat kialakításáról,

- gondoskodik az irányítása és felügyelete alá tartozó szervek védekezésre való felkészítéséről és működési feltételeinek biztosításáról, jóváhagyja a feladatok végrehajtását szolgáló terveket,

- ellenőrzi a megelőzéssel és a felkészüléssel kapcsolatos ágazati feladatok végrehajtását.

- Végzi a katasztrófák elleni védekezés feladatkörében az ágazati kockázatbecslési feladatokat,

- a biztonsági elemzések eredményei alapján javaslatot tesz az ágazati katasztrófavédelmi biztonsági célkitüzésekre és biztonságpolitikára,

- részt vesz a nemzeti és nemzetközi katasztrófavédelmi gyakorlatok tervezésében, szervezésében és végrehajtásában.

\section{Katasztrófavédelmi Koordinációs Tárcaközi Bizottság (KKB)}

A szervezet ezzel a megnevezéssel és összetételben 2012 óta működik, jogelődje 2000töl a miniszterelnök által vezetett Katasztrófavédelmi Koordinációs Kormánybizottság volt. Felépítését tekintve elnöke a belügyminiszter, tagjai a miniszterek által kijelölt állami vezetők (rendszerint szakmai vagy közigazgatási államtitkárok), a tanácskozási joggal részt vevő állandó tagok közt szerepel a BM OKF főigazgató, az országos rendőrfőkapitány, a Magyar Honvédség parancsnoka, a KKB Tudományos Tanácsának elnöke, a KKB Nemzeti Veszélyhelyzet-kezelési Központ vezetője, a Belügyminisztérium közbiztonsági föigazgatója és a BM OKF Védelemigazgatási és Koordinációs Főosztály 
vezetője. ${ }^{11}$ A kezelendő helyzet függvényében több más meghívható tag lehet, például az Országos Mentőszolgálat elnöke.

A Nemzeti Veszélyhelyzet-kezelési Központ a KKB operatív szerve, amely - elrendelés esetén - 24 órás munkarendben müködik folyamatosan.

„A Kormány javaslattevő, véleményező és tanácsadói tevékenységet végző szervként hozta létre a KKB-t. Szervezeti és müködési rendjét kormányhatározat tartalmazza, amely értelmében a bizottság a katasztrófavédelemmel összefüggésben döntés-előkészítő, valamint a katasztrófák elleni felkészüléssel, megelőzéssel, védekezéssel és helyreállítással kapcsolatban koordinációs feladatokat lát el."12

A KKB koordinációs és kormányzati döntés-előkészítő feladatokat lát el, így: ${ }^{13}$

- összehangolja a katasztrófák elleni védekezés terén a tudományos, kutató, elemző, értékelő tevékenységet, éves feladattervében meghatározza az ágazati felkészüléssel kapcsolatos feladatokat,

- összehangolja az ország egészét érintő katasztrófák elleni védekezési rendszergyakorlatok tervezését, szervezését, figyelemmel kíséri a két- és többoldalú nemzetközi megállapodásokban foglaltak végrehajtását,

- összehangolja a védekezésben részt vevő központi államigazgatási szervek védekezésével kapcsolatos szakmai tevékenységet,

- több megyét érintő katasztrófa esetében összehangolja a védekezésben részt vevő területi szervezetek feladataira és az anyagi eszközök átcsoportosítására irányuló ágazati feladatokat,

- javaslatot tesz a felmerült védekezési költségek biztosítására,

- kezdeményezi a Kormány döntését a veszélyhelyzet kihirdetésére,

- javaslatot tesz a felmerült védekezési és helyreállítási pénzeszközök felhasználására,

- összehangolja a helyreállítással kapcsolatos feladatok végrehajtását, a kárfelmérést, a kormányzati pénzeszközök, valamint segélyek felhasználását.

\section{Összefoglalás}

Jelen tanulmány röviden összefoglalta a közigazgatás - ezen belül a kormány - védelmi funkcióinak egyik, a katasztrófavédelemmel összefüggő területét. Ismertette a kormány, a belügyminiszter és a Kormányzati Koordinációs Tárcaközi Bizottság legfontosabb, a katasztrófák megelőzésével és az ellenük való védekezéssel kapcsolatos, a védelmi igazgatás fogalomkörébe tartozó feladatait.

A tanulmány következő részében bemutatom a nemzeti katasztrófavédelmi rendszer országos, területi és helyi szintjeit.

11 1150/2012. (V. 15.) Korm. határozat a Katasztrófavédelmi Koordinációs Tárcaközi Bizottság létrehozásáról, valamint szervezeti és működési rendjének meghatározásáról 1. melléklet 2., 3., 4. pont.

12 Baán Mihály et al.: Magyarország védelmi igazgatása a közigazgatás új rendszerében, Zrínyi Kiadó, Budapest, $2014,81$.

13 234/2011. (XI. 10.) Korm. rendelet a katasztrófavédelemről és a hozzá kapcsolódó egyes törvények módosításáról szóló 2011. évi CXXVIII. törvény végrehajtásáról 8. §. 


\section{Felhasznált irodalom}

2011. évi CXXVIII. törvény a katasztrófavédelemről és a hozzá kapcsolódó egyes törvények módosításáról

234/2011. Korm. rendelet a katasztrófavédelemröl és a hozzá kapcsolódó egyes törvények módosításáról szóló 2011. évi CXXVIII. törvény végrehajtásáról

1150/2012. Korm. határozat a Katasztrófavédelmi koordinációs Tárcaközi Bizottság létrehozásáról, valamint szervezeti és működési rendjének meghatározásáról

Baán Mihály - Bors István - Csiffáry Tamás - Hári László - Kocsis Lajos -Szentes László: Magyarország védelmi igazgatása a közigazgatás új rendszerében. Zrínyi Kiadó, Budapest, 2014.

Endrődi István: A katasztrófavédelem tevékenysége veszélyhelyzeti feladatok végrehajtása során, in: Kovács Gábor (szerk.), A rendészeti, honvédségi, közigazgatási és nemzetközi szervezetek tevékenysége veszélyhelyzet-ben, A „Vihar-2016" Egyetemi Közös Közszolgálati Gyakorlat tapasztalatai, Nemzeti Közszolgálati Egyetem, Budapest, 2016.

Kovács Gábor (szerk.): A rendészeti, honvédségi, közigazgatási és nemzetközi szervezetek tevékenysége veszélyhelyzetben, A „Vihar-2016" Egyetemi Közös Közszolgálati Gyakorlat tapasztalatai, Nemzeti Közszolgálati Egyetem, Budapest, 2016.

A védelmi Igazgatás a Közigazgatás és a Honvédelmi Igazgatás kapcsolata, http:// csongrad.katasztrofavedelem.hu/letoltes/document/csongrad/document_267. pdf (Letöltve: 2019. 02.01.)

Magyarország Alaptörvénye

Schweickhardt Gotthilf: A katasztrófavédelem rendszere, Nemzeti Közszolgálati Egyetem, Dialóg Campus Kiadó, Budapest, 2018. 